\title{
Optimization of Online Learning Planning Courses of Low Class Indonesian Language and Literature Education in PGSD FIP Students State University Of Medan
}

\author{
$1^{\text {st }}$ Masta Marselina Sembiring ${ }^{1}, 2^{\text {nd }}$ Erlinda Simanungkalit ${ }^{2}, 3^{\text {rd }}$ Dody FP Ambarita $^{3}$ \\ \{mastamasselina@unimed.ac.id ${ }^{1}$, erlinda@unimed.ac.id ${ }^{2}$, dodyambarita@gmail.com ${ }^{3}$ \} \\ Department of Primary School Teacher Education, Faculty of Science Education, Universitas Negeri \\ Medan, Indonesia ${ }^{1,2,3}$
}

\begin{abstract}
This study aims to: (1) To develop an Online Lecture Learning Plan that meets the requirements (valid) as interactive learning in Low Class Indonesian Language and Literature Education Lectures. (2) Describe student responses to the use of Online Lecture Learning Planning Development in the Low Grade Indonesian Language and Literature Education Course. The research method uses research and development (R\&D) methods from R\&D research methods, by developing 10 steps of Borg and Gall development. The location of the research was carried out at the location where the research was carried out in the PGSD FIP Unimed study program which was located on Jl. Willem Iskandar / Pasar V, Medan, North Sumatra. The population of this study was all students of PGSD Unimed Stambuk 2020 totaling 225 students consisting of 11 (A-K) regular and extension classes. The sample of this study was randomly assigned to classes and one class was selected, namely the J Regular 2020 class, which consists of 30 students. The results showed that: the quality of the online lecture learning planning validity met the valid criteria based on the average score of $85.3 \%$ of the maximum score of $100 \%$ with very feasible criteria. The learning tools developed have met the effectiveness criteria by: a) classical learning completeness has exceeded the minimum limit, namely in the second trial of $88 \%$. b) The quality of the learning tools meets the good criteria based on the average score of $95 \%$ student response questionnaires from a maximum of $100 \%$. c) students ${ }^{\wedge}$ thinking skills have increased, namely the average value in the first trial of $41.3 \%$, an increase of $46.7 \%$ to $88 \%$ in the second trial and the number of students who completed the first trial $13.4 \%$ an increase of $86,6 \%$ to $100 \%$ in trial II. It is concluded that the Development of Online Lecture Learning Planning meets the requirements (valid) as interactive learning in the Low Class Indonesian Language and Literature Education Lecture.
\end{abstract}

Keywords: Optimization, Planning, Learning, Online, Indonesian Language Education, Low Class.

\section{Introduction}

Education is a conscious and planned effort to create a learning atmosphere and learning process so that students actively develop their potential to have spiritual, religious, selfcontrol, personality, intelligence, noble character, and skills needed by themselves, society, 
nation and state. (Law on the National Education System No. 20 of 2003 article 1). Education must encourage people to be involved in the process of changing lives for the better, developing self-confidence, developing curiosity and increasing the knowledge and skills they have throughout life. School is an educational institution that can be a bridge to achieve all of these things. In improving the quality of human resources through one of the educational institutions, namely schools, especially elementary schools as the first formal educational institutions that are responsible for developing attitudes, potential and providing basic knowledge and skills for students through the learning process. One of the factors in the success of the learning process is the teacher. Quality teachers will produce quality learning. The current development of Information and Communication Technology, teachers have challenges to be able to use Information and Communication Technology in the learning system so that learning can be more interesting and fun. potential and provide basic knowledge and skills for students through the learning process. One of the factors in the success of the learning process is the teacher. Quality teachers will produce quality learning. The current development of Information and Communication Technology, teachers have challenges to be able to use Information and Communication Technology in the learning system so that learning can be more interesting and fun. potential and provide basic knowledge and skills for students through the learning process. One of the factors in the success of the learning process is the teacher. Quality teachers will produce quality learning. The current development of Information and Communication Technology, teachers have challenges to be able to use Information and Communication Technology in the learning system so that learning can be more interesting and fun.

The Low Grade Indonesian Language and Literature Education course is a compulsory subject in the Group of Lecturers in the field of study clump for Indonesian Language and Literature Education in elementary schools. This course focuses on studying 5 main topics, namely: listening, speaking, reading, writing, and appreciation of literature in the lower grades of elementary school. Students will be given concepts related to the topics discussed, which lead to improve skills in designing and simulating learning to listen, speak, read, write, and appreciate literature in the lower grades of elementary school.

There are 3 competency achievements that must be mastered by students in this course, including: (1) Comparing the substance and basic methodology of Indonesian language and literature in lower grades, including: listening, speaking, reading, writing, and literary appreciation; (2) Developing an integrated learning design and authentic assessment of Indonesian language and literature learning in the lower grades of elementary school; and (3) Simulating the integrated learning of Indonesian language and literature in the lower elementary grades. Thus, through this course, students not only understand the concepts and theories of listening, speaking, reading, writing, and appreciation of literature in lower elementary grades, but can design learning and simulate it in the form of direct peer teaching learning with peers.

Connected with the spread of the corona virus pandemic or COVID-19 in Indonesia, many universities and schools have stopped the face-to-face learning process. So that researchers face a new phenomenon regarding the learning system. Based on the announcement made by the Minister of Education and Culture Nadiem Makarim admitted that he was studying the possibility of implementing an emergency curriculum due(to conditions that required studying at home during the coronavirus pandemic (Covid-19). In addition, students must also be ready to adapt to changes in learning regulated by schools and universities. Remote learning can be seen as more freely and flexibly accessed from home. 
Responding to the Covid-19 issue as a lecturer as well as a researcher must be able to develop innovative and creative learning tools. One of them is developing teaching materials as learning resources, namely the availability that can be reached by students, can help students learn independently, and facilitate students on complete and up-to-date teaching materials. Good material must be packaged attractively according to the subject and equipped with pictures, illustrations, examples of questions or contextual cases that are adequate to support teaching. Utilization of information technology,

E-learning is an information and communication technology that allows students to learn anytime and anywhere [1]. Electronic learning or e-learning has started in the 1970s [2]. Various terms are used to express opinions/ideas about electronic learning, including: online learning, internet-enabled learning, virtual learning, or web-based learning. There are 3 (three) important things as requirements for electronic learning activities (e-learning), namely: (a) learning activities are carried out through the use of networks, in this case limited to the use of the internet, (b) the availability of support for learning services that can be utilized by participants. learning, for example External Harddisk, Flashdisk, CD-ROM, or printed materials, and (c) the availability of tutor support services that can help participants learn if they have difficulties. In addition to the three requirements above, other requirements can still be added, such as: (a) institutions that organize and manage e-learning activities, (b) positive attitudes of students and coaching staff towards computer and internet technology, (c) design a learning system that can be learned and known by every learner, (d) an evaluation system of the learning progress or development of learning participants, and (e) a feedback mechanism developed by the organizing institution.

Based on the problems above, the researcher plans the Optimization of Learning Planning Low Grade Indonesian Language and Literature Education courses are planned with a system online learning is used appropriately and clearly. So the idea of solving the issue was made, namely 'Optimizing Online Lecture Planning by developing Syllabus, RPS, Evaluation of online lectures and Teaching Materials made in the form of a digital book'. For this reason, researchers also took the initiative to create e-Books that are creative, interactive, interesting and informative. Thus, it is expected that the delivery of digital electronics material will be maximized, more easily understood by students, students will not feel bored in receiving lessons, and can be motivated to learn more. In addition, with e-books, it is expected that students are not only motivated during lessons but are also motivated to learn outside class hours and are able to experiment with the material presented.The title of the research title for the novice lecturer is "Optimizing Online Learning Planning for Low Grade Indonesian Language and Literature Education Courses for PGSD Students, Faculty of Education, State University of Medan".

\section{Method}

This research uses research and development methods or often called Research and Development (R\&D). Research and development is a research method to develop and test products in the world of education. In addition to developing and testing products, this research is used to discover new knowledge regarding fundamental phenomena, as well as educational practices. Functioning to find fundamental phenomena is done through basic research. Then for research on educational practices, applied research is conducted. [3] R\&D research is a research method used to produce certain products, and test the effectiveness of 
these products. In order to produce a product, using research that is a needs analysis to test the effectiveness of the product so that it can function for the wider community, research is needed to test the effectiveness of the product. In research and development, this is longitudinal, meaning that it is carried out in stages. This research and development method, in addition to being used in the natural sciences and engineering division, can also be used in other fields of science. This research is suitable for product development. In developing the R\&D research method, the researcher developed 10 steps of Borg and Gall development. In research and development, this is longitudinal, meaning that it is carried out in stages. This research and development method, in addition to being used in the natural sciences and engineering division, can also be used in other fields of science. This research is suitable for product development. In developing the $R \& D$ research method, the researcher developed 10 steps of Borg and Gall development. In research and development, this is longitudinal, meaning that it is carried out in stages. This research and development method, in addition to being used in the natural sciences and engineering divisions, can also be used in other fields of science. This research is suitable for product development. In developing the R\&D research method, the researcher developed 10 steps of Borg and Gall development.

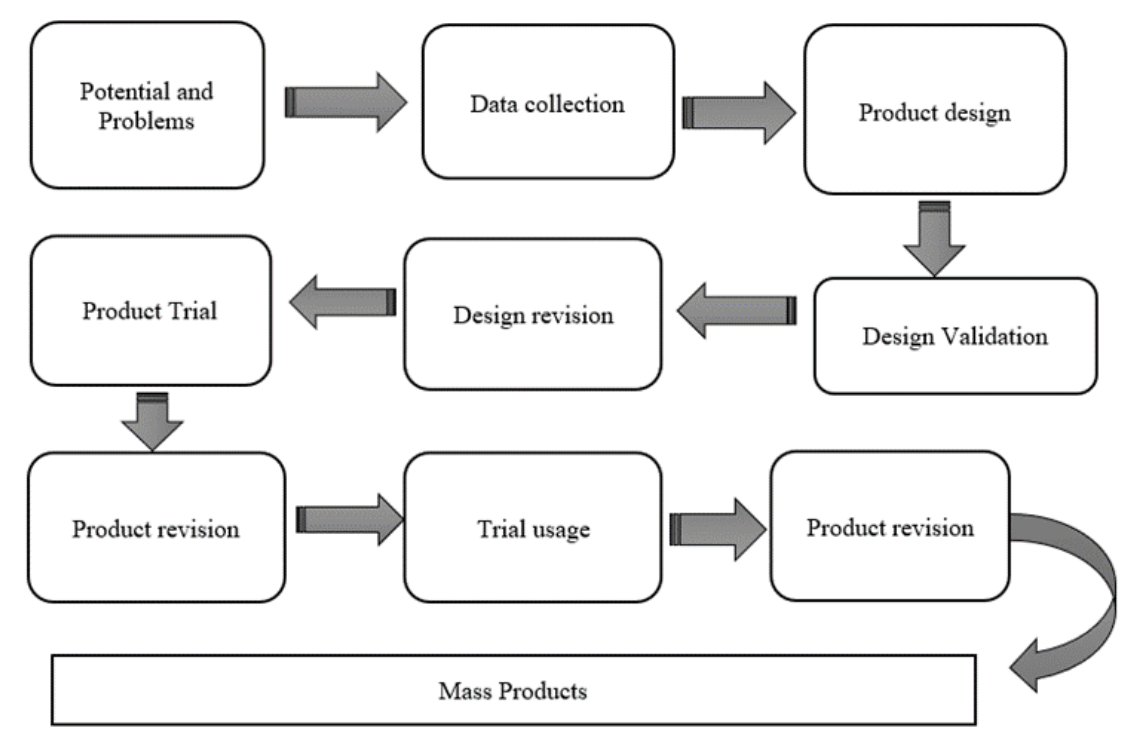

Fig. 1. Steps of R\&D Research (Research and Development).

The location of the research was carried out in the PGSD FIP Unimed study program which was located on Jl. Willem Iskandar / Pasar V, Medan, North Sumatra - Indonesia Postal Box 1589, Postal Code 20221, Tel. (061) 6613365, Fax. (061) 6614002 / 6613319. The population of this research is all students of PGSD Unimed force 2020 totaling 225 students consisting of 11 (AK) regular and extension classes. The sample of this research was carried out in a class program and one class was selected, namely the 2020 Regular J class, which consisted of 40 students. 


\section{Results and Discussion}

The results of the validation and revision of the learning tools: The assessment carried out by the validator includes the feasibility of content, presentation of material, appearance and language. In making revisions, the researcher refers to the results of the discussion by following the suggestions and instructions of the validator. The results of the material expert and media expert validator onLearning Planning Online Lectures for Low Grade Indonesian Language and Literature Education Courses in the form of digital books as follows.

Table 1. Expert Validation Results of Learning Planning Materials for Online Lectures for Low Class Indonesian Language and Literature Education Courses.

\begin{tabular}{lcccc}
\hline \multicolumn{1}{c}{$\begin{array}{c}\text { Assessment } \\
\text { criteria }\end{array}$} & Number & $\begin{array}{c}\text { Max Total } \\
\text { Score }\end{array}$ & $\begin{array}{c}\text { Score } \\
\text { Achieved }\end{array}$ & Classification \\
\hline Material Load & $1,2,3$ & 15 & 10 & Worthy \\
Material & $4,5,6,7$ & 20 & 12 & Worthy \\
Presentation & & & & Worthy \\
Language & $8,9,10$ & 15 & 12 & $34 / 50=68 \%$ \\
Total number & & 50 & 34 & \\
\hline
\end{tabular}

Table 2. Validation Results of Media Experts on Learning Planning Online Lectures for Low Class Indonesian Language and Literature Education Courses.

\begin{tabular}{lccc}
\hline Assessment criteria & $\begin{array}{c}\text { Total Score/ } \\
\text { Aspect }\end{array}$ & Achieved Score & Classification \\
\hline Content/Content & 15 & 15 & Very Worthy \\
Design/ Appearance & 55 & 48 & Worthy \\
Use/Presentation & 10 & 10 & Very Worthy \\
Language & 20 & 20 & Very Worthy \\
Total number & & 100 & $93 / 100=93 \%$ \\
\hline
\end{tabular}

Table. 3. Validation Results of Media Experts and Material Experts.

\begin{tabular}{cccc}
\hline No. & Validator & Score & Category \\
\hline 1 & Material Expert & 68 & Worthy \\
2 & Media Expert & 93 & Very Worthy \\
& Amount & 161 & \\
& Average & $80.5 \%$ & \\
& Category & Worthy & \\
& & &
\end{tabular}

Based on table 3. it is obtained that the total average for the validation of Online Lecture Learning Planning for Low Grade Indonesian Language and Literature Education Courses in the form of digital is $80.5 \%$. By referring to these criteria, it can be concluded that the Online Learning Planning for Low Grade Indonesian Language and Literature Education Courses in the form of digital books developed meets the criteria for validity in the "valid" category. 
Furthermore, the product that has been validated is tested on students and distributed questionnaires to obtain the results of student responses. The results of student responses are described in the table below.

Table 4. Recapitulation of Student Response Results.

\begin{tabular}{cccc}
\hline Learners & Score & Average & Category \\
\hline 1. & 88 & 4.4 & Worthy \\
2. & 100 & 5 & Very Worthy \\
3. & 93 & 4.65 & Very Worthy \\
4. & 95 & 4.75 & Very Worthy \\
5. & 94 & 4.7 & Very Worthy \\
6. & 94 & 4.7 & Very Worthy \\
7. & 96 & 4.8 & Very Worthy \\
8. & 100 & 5 & Very Worthy \\
9. & 93 & 4.65 & Very Worthy \\
10. & 95 & 4.75 & Very Worthy \\
11. & 91 & 4.55 & Very Worthy \\
12. & 94 & 4.7 & Very Worthy \\
13. & 97 & 4.85 & Very Worthy \\
14. & 96 & 4.8 & Very Worthy \\
15. & 100 & 5 & Very Worthy \\
Amount & 1.426 & 71.3 & Very Worthy \\
Average & $95 \%$ & 4.75 & Very Worthy \\
\hline
\end{tabular}

Based on Table 4. above shows that the overall score of the questionnaire is $95 \%$. From these acquisitions, an average of 4.75 was obtained and was included in the "Very Eligible" category. The data obtained from the results of the pretest and posttest of students' visual thinking abilities were analyzed to determine the Online Learning Planning of the Low Grade Indonesian Language and Literature Education Course by comparing the average student scores obtained from the pretest and posttest results. The description of the improvement in Learning Planning for Online Lectures for Low Grade Indonesian Language and Literature Education Courses developed in the pretest and posttest is shown in table 5 below.

Table 5. The Average Value of Pretest and Posttest Students.

\begin{tabular}{ccc}
\hline Information & Pretest & Posttest \\
\hline The highest score & 80 & 100 \\
Lowest Value & 20 & 80 \\
Average & 41.3 & 88 \\
\hline
\end{tabular}

Based on table 5. the results of the analysis of the increase in pretest and posttest students showed that the pretest results were $41.3 \%$, an increase of $88 \%$. The increase in students is $46.7 \%$. The increase in the average of students from the results of the pretest and posttest using the N-Gain formula: From the results of the N-Gain calculation, it was found that an increase in student learning outcomes was 0.79 which was included in the high criteria. It can be concluded that the Online Learning Planning of Low Grade Indonesian Language and 
Literature Education Courses in the form of digital books has been improved through the application of developed learning tools.

The discussion of the results of this study will describe descriptively and interpretations of the validity and effectiveness of the learning tools developed and the improvement of students' abilities. The factors involved in the research are development factors, learning factors, and students' thinking ability factors. The learning device developed has met the valid word. That is, the development of learning tools has been in accordance with the concepts and further indicators are adjusted to the characteristics of the learning tools developed. The fulfillment of a good validity aspect as stated above is in line [4], which states that the validity aspect refers to the extent to which the device design is developed.

The learning device developed in this research is the Online Lesson Learning Plan for the Low Grade Indonesian Language and Literature Education Course in the form of a digital book. All learning devices have gone through a validation process by the validator. The total average validation value for Online Lecture Learning Planning for Low Grade Indonesian Language and Literature Education Courses in the form of digital books is $85.3 \%$. The value for the total average of Online Lecture Learning Planning for Low Grade Indonesian Language and Literature Education Courses in the form of digital books is included in the valid category. The results of development research are supported by the opinion [5] which is based on the results of the development of learning tools that have met the valid criteria.

Results of Online Lecture Learning Planning for Low Grade Indonesian Language and Literature Education Courses in the form of a learning digital book that was developed to meet the effective criteria seen from the achievement of students' classical visual thinking skills. This criterion is met if it is more than or equal to $80 \%$ of students with an average score of at least 75 (complete category). The results of the first trial analysis on visual thinking skills obtained 2 students who completed or $13.4 \%$ in the pretest trial I. The results of the pretest trial I did not meet the established effective criteria, therefore trial II was carried out as a process of repairing the device. learning. The results of the second trial posttest there were 15 students who completed or $86.6 \%$. The results of the posttest trial II have met the criteria for achieving students' visual thinking skills. The results of this study indicate that students' visual thinking skills have shown effective criteria. Thus the learning tools developed have met the effective criteria.

\section{Conclusion}

Learning Planning Online Lectures for Low Grade Indonesian Language and Literature Education Courses in the form of digital books have met the effective criteria in terms of classical student completeness which has been achieved $88 \%$ and the learning tools developed have met the effective criteria in terms of student response questionnaires to the learning tools used. developed already meet the specified criteria, namely "feasible". The validity of the learning tools developed is included in the valid category with an average total validity of 85.3\%. The improvement of students' visual thinking skills using Online Lecture Learning Planning for Low Grade Indonesian Language and Literature Education Courses in the form of digital books is the average achievement of students' visual thinking skills in the first trial of $41.3 \%$, increasing to $88 \%$ in the second trial. 


\section{References}

[1] Dahiya S, Jaggi S, Chaturvedi KK, Bhardwaj A, Goyal RC, Varghese C. An eLearning System for Agricultural Education. Indian Res J Extension Educ. 2016; 12(3):132-135.

[2] Waller V, Wilson J. A Definition for E-Learning” in Newsletter of Open and Distance Learning Quality Control. Available from: http://www.odlqc.org.uk/odlqc/n19-e.html [Accessed October 2020].

[3] Sugiyono. Quantitative, Qualitative and R\&D Research Methodology. Bandung: Alphabeta; 2015. 407.

[4] Amri S. Development \& Learning Models in the 2013 Curriculum. Jakarta: PT. Library Achievement; 2013. 207.

[5] Syahbana A. Improving Students' Mathematical Critical Thinking Ability SMP through Contextual Teaching and Learning Approach. J Edumatica. 2012; 2(1):45-57. 